\title{
Gender of transformational school principals and teachers' innovative behavior
}

Aziah Ismail, Nor Shafrin Ahmad, Rahimi Che Aman

School of Educational Studies, University Sains Malaysia, Malaysia

\begin{tabular}{l} 
Article Info \\
\hline Article history: \\
Received Jan 9, 2021 \\
Revised Jun 12, 2021 \\
Accepted Jul 13, 2021 \\
\hline
\end{tabular}

\section{Keywords:}

Educational management Gender

Innovative behavior

School principals

Transformational leadership

\begin{abstract}
The purpose of this paper is to examine the different levels of transformational leadership between male and female principals and their relationships with teachers' Innovative Work Behavior (IWB) in Malaysian secondary schools. In total, 477 teachers from various secondary schools were randomly selected as respondents (218 are working under female principals, while 259 of them are under male principals). This study revealed that the respondents agree that male principals practice transformational leadership higher than female principals. However, the female principals were highly influential on the teachers' IWB compared to their male counterparts. This study provides a glimpse of the teachers' innovative behavior improvement resulted from transformational leadership by male and female school principals.
\end{abstract}

This is an open access article under the CC BY-SA license.

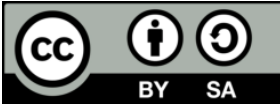

\section{Corresponding Author:}

Aziah Ismail

School of Educational Studies

Universiti Sains Malaysia

11800 Penang, Malaysia

Email: aziah@usm.my

\section{INTRODUCTION}

Many recent studies claimed that innovative work behavior, which has been revealed as one of the essential contributors to organizational performance [1], [2] and an essential aspect of high-quality education [3], [4], is inherently associated with transformational leadership [4]-[7]. Bass and Avolio confirmed that under effective transformational leaders, organizations flourished. Workers recorded greater work satisfaction as they embraced management systems' enhancement and significantly increased employees' talent to improve productivity [8].

While previous literature has given the relationship between transformational leadership and job performance (i.e., innovative work behavior) considerable attention, there are previous researchers [9]-[12] who have been trying to relate gender with transformational leadership and job performance. Many researchers agreed that gender has a critical impact on leadership performance [13]-[17]. For instance, Bark, et al. asserted that female leaders lead slightly more effectively than male leaders [12]. However, Reuvers, et al. in their study, indicated that employees reported become more innovative when their male leaders display transformational leadership in comparison to their female leaders [16]. Although previous studies have revealed extensive empirical evidence regarding the direct effect of transformational leadership on innovative work behavior [8], [16], [18]-[20], the aspect of gender still needs to be considered in the research framework.

Nowadays, the roles of women in leadership are increasing and becoming an emerging trend globally. Many researchers in the organizational leadership and management area have attempted to provide evidence on gender differences in leadership and their influence on subordinates and the organization 
environment. Findings from the studies contradicted and triggered organizations to relate the leaders' skills and knowledge with their gender. According to Emmerick, Wendt, and Euwema, studies on gender differences in leadership are mainly based on Western data. There is a need to incorporate studies in nonWestern cultures, such as Asian countries [21]. For example, there is relatively scarce evidence of gender differences in transformational leadership in Malaysian school though women have increasingly moved toward greater gender equality in the organization. While this country is categorized as developing countries and typically dominated by patriarchal societies, the statistics have revealed a consistent increment in women's leadership positions in for-profit and non-profit organizations. According to Gender Diversity Benchmark for Asia 2011 (CB 2011), as cited by Cho, et al. Malaysia performed best in women's senior positions (27.6\% versus an average of $18.3 \%$ ) compared to Hong Kong and China which rated as the highest percentage female employees of the respective countries' workforce [22]. The percentage of women leaders had increased from $24 \%$ (2017) to $28 \%$ (2018) [23]. Inevitably, public schools in Malaysia are also experiencing an increased number of female principals [24]. As reported by the Ministry of Education Malaysia, almost half of the secondary schools (49\%) in Malaysia led by female principals [25]. Meanwhile, in 2017 , female teachers represented about $72 \%$ of the overall number of teachers in Malaysia, with $37.2 \%$ of them are school leaders (headmistress and principals) [26].

The tremendous increment of female leaders in Malaysian schools leads to a call for a study to examine and understand gender differences in leadership behavior and their influence on subordinates and organization. Studies on gender and leadership in Malaysia have mainly focused on female leadership [10], [24], [27], but none of them compared their style to that of the male leadership. Thus, this research aims to study the discrepancies of male and female school principals' transformational leadership in Malaysia and its relation to teachers' innovative behavior. More specifically, this study attempts to answer the following questions: 1) Is there any significant difference in transformational leadership between male and female principals than their female counterparts?; 2) Is there any significant relationship between transformational leadership and Malaysian teachers' innovative work behavior?; 3) Is the strength of the relationship more decisive in the female transformational leadership than that of the male?

\section{RESEARCH METHOD}

\subsection{Sampling}

The study based on a survey conducted in secondary schools in three states in the northern part of Peninsular Malaysia, namely Penang, Kedah, and Perlis. A total of 500 questionnaires were distributed to the 50 schools from these three states (e.g., Perlis: 10 schools; Kedah: 20 schools; and Penang: 20 schools), 25 of the schools led by male leaders and the other 25 led by female principals. The proportion was made based on the total of secondary schools in each state. Five hundred teachers were selected from the selected schools using a systematic random sampling technique, with ten respondents from each school. In selection procedures, researchers have selected every 5th name (for instance 5, 10, 15) in teachers' registration list of the schools as the respondents. From 500 questionnaires distributed, only 477 of them have the complete answer and used for the analysis. 218 were from teachers led by female principals, while 259 others were from teachers who led by male principals. Informed consent has been obtained from all participants as required by the Human Research Ethics Committee USM (HREC) in an approval letter (USM/JEPeM/16010001).

As presented in Table 1, the respondents' demographics backgrounds divided into two, based on their leaders' gender. The mean age of 259 male respondents representing the male leaders' category is 39.24 $(\mathrm{SD}=7.88)$ years. As for their experiences in the current employment, the mean is $8.22(\mathrm{SD}=5.73)$ years. Meanwhile, the mean age of 218 female respondents who represented the female leaders' category is 40.220 $(\mathrm{SD}=8.54)$, with a mean of experiences of $7.811(\mathrm{SD}=5.33)$. The majority of the respondents under the leadership of male leaders holding a bachelor's degree is $201(77.61 \%)$, while this is $183(83.94 \%)$ under the leadership of female leaders with the same qualification.

Table 1. Demographics of respondents by gender of leaders

\begin{tabular}{|c|c|c|c|}
\hline \multicolumn{2}{|c|}{ Characteristics } & Male leader $(\mathrm{n}=259)$ & Female leader $(n=218)$ \\
\hline \multirow[t]{2}{*}{ Age } & Mean & 39.24 & 40.22 \\
\hline & SD & 7.88 & 8.54 \\
\hline \multirow{2}{*}{ Experience (years) } & Mean & 8.22 & 7.81 \\
\hline & SD & 5.73 & 5.33 \\
\hline \multirow[t]{4}{*}{ Education } & Diploma & $6(2.30 \%)$ & $12(5.50 \%)$ \\
\hline & Bachelor & $201(77.60 \%)$ & $183(83.90 \%)$ \\
\hline & Masters & $48(18.50 \%)$ & $22(10.10 \%)$ \\
\hline & $\mathrm{PhD}$ & $4(1.50 \%)$ & $1(0.50 \%)$ \\
\hline
\end{tabular}

Int J Eval \& Res Educ, Vol. 10, No. 3, September 2021: 747 - 752 


\subsection{Instrument}

This study consisted of three variables; Transformational Leadership (independent variable) and Teachers' Innovative Work Behavior as the dependent variables. A questionnaire consisting of three parts were utilized for data gathering. The parts are as: 1) Section A: Respondents' demographics background (e.g., age, years of experience, level of education); 2) Section B: Transformational leadership was measured using Bass and Avolio's multifactor leadership questionnaire (MLQ) [28]; and 3) Section C: Teachers' innovative work behavior containing the nine items adapted from Janssen [29].

\section{RESULTS AND DISCUSSION}

\subsection{Mean score and t-test analysis}

Table 2 presents the mean scores and standard deviations of the sub-dimensions of Transformational Leadership and t-test values that measure the differences between the means rated by the respondents for their male or female principals' transformational leadership. The mean score of transformational leadership and its sub-dimensions reveals that the male principals are more transformational than their female counterparts, with their inspirational motivation in the highest level (male: $\mathrm{M}=3.90, \mathrm{SD}=.64$; female: $\mathrm{M}=3.56, \mathrm{SD}=.74$ ), followed by intellectual stimulation (male: $\mathrm{M}=3.79, \mathrm{SD}=.65$; female: $\mathrm{M}=3.52, \mathrm{SD}=.82$ ), individualized consideration (male: $\mathrm{M}=3.75, \mathrm{SD}=.70$; female: $\mathrm{M}=3.33, \mathrm{SD}=.81$ ), and idealized influence (male: $\mathrm{M}=3.68, \mathrm{SD}=.69$; female: $\mathrm{M}=3.28, \mathrm{SD}=.77$ ).

Meanwhile, independent-samples t-tests were employed to compare transformational leadership between male and female principals. There are significant differences in the scores for the male principals $(\mathrm{M}=3.78, \mathrm{SD}=.62)$ and female principals $(\mathrm{M}=3.42, \mathrm{SD}=.74) ; \mathrm{t}(475)=5.79, \mathrm{p}=.001$. The t-test result also reveals the significant difference rated by the respondents for each sub-dimension of transformational leadership between the male and female principals.

Table 2. Mean score, standard deviation, and t-test of sub-dimensions of transformational leadership

\begin{tabular}{|c|c|c|c|c|c|c|}
\hline \multirow{2}{*}{ Dimensions } & \multirow{2}{*}{$\begin{array}{c}\text { Gender of } \\
\text { leader }\end{array}$} & \multirow{2}{*}{ Mean } & \multirow{2}{*}{$\begin{array}{c}\text { Std. } \\
\text { Deviation }\end{array}$} & \multicolumn{3}{|c|}{ t-test for equality of means } \\
\hline & & & & $\mathrm{t}$ & df & Sig. (2-tailed) \\
\hline \multirow{2}{*}{ Idealized influence } & Male & 3.68 & .69 & \multirow{2}{*}{6.03} & \multirow{2}{*}{475} & \multirow{2}{*}{$.001 * *$} \\
\hline & Female & 3.28 & .77 & & & \\
\hline \multirow{2}{*}{ Intellectual stimulation } & Male & 3.79 & .65 & \multirow{2}{*}{5.73} & \multirow{2}{*}{475} & \multirow{2}{*}{$.001 * *$} \\
\hline & Female & 3.52 & .82 & & & \\
\hline \multirow{2}{*}{ Inspirational motivation } & Male & 3.90 & .64 & \multirow{2}{*}{5.48} & \multirow{2}{*}{475} & \multirow{2}{*}{$.001 * *$} \\
\hline & Female & 3.56 & .74 & & & \\
\hline \multirow{3}{*}{ Individualized consideration } & Male & 3.75 & .70 & \multirow{3}{*}{6.17} & \multirow{3}{*}{475} & \multirow{3}{*}{$.001 * *$} \\
\hline & Female & 3.33 & .81 & & & \\
\hline & Female & 3.52 & .82 & & & \\
\hline \multirow{2}{*}{ Transformational leadership } & Male & 3.78 & .62 & \multirow{2}{*}{5.79} & \multirow{2}{*}{475} & \multirow{2}{*}{$.001 * *$} \\
\hline & Female & 3.42 & .74 & & & \\
\hline
\end{tabular}

**significant at $\mathrm{p}<.01$

\subsection{Correlation among variable}

A Pearson product-moment correlation was conducted to assess the relationship between transformational leadership and IWB, in the schools led by male and female principals. The split-half data feature in IBM SPSS 24 was utilized to have separate correlation analyses. The results were based on a group of respondents led by male and female principals.

Table 3 shows the correlation coefficient results for the male and female principals. The results show that there is positive significant correlation between the three main variables; transformational leadership and IWB (male principals: $\mathrm{r}=.49, \mathrm{n}=259, \mathrm{p}=.001$; female principals: $\mathrm{r}=.65, \mathrm{n}=218, \mathrm{p}=.001$ ); transformational leadership and POPs (male principals: $\mathrm{r}=.27, \mathrm{n}=259, \mathrm{p}=.001$; female principals: $\mathrm{r}=.33$, $\mathrm{n}=218, \mathrm{p}=.001$ ) and; POPs and IWB (male principals: $\mathrm{r}=.31, \mathrm{n}=259, \mathrm{p}=.001$; female principals: $\mathrm{r}=.34$, $\mathrm{n}=218, \mathrm{p}=.001)$.

Table 3. Correlation between transformational leadership and IWB

\begin{tabular}{lcc}
\hline Variables and dimensions & Gender of leaders & Innovative work behavior \\
\hline Transformational leadership & $\mathrm{M}$ & $.49^{* *}$ \\
**significant at $\mathrm{p}<.01$ & $\mathrm{~F}$ & $.65^{* *}$ \\
\hline
\end{tabular}


In general, the results indicate that transformational leaders (regardless of their gender) can increase the teachers' IWB. Furthermore, the r-value also indicates that the relationship between the variables is higher for female principals than male principals. This result indicates that although the female principals' level of transformational leadership is lower than that of the male principals, it is strongly associated with the teachers' IWB compared to their male counterparts.

\section{DISCUSSION}

This study attempts to advance knowledge about the relationship between transformational leadership and innovative work behavior. Although this study followed similar studies that moved in the same direction [13], [14], [17], [21], it sought to extend them to create an understanding of leadership concept in education by examining the interrelation model based on the principal's gender. The results reveal significant differences between the male and female principals of Malaysian secondary schools practicing transformational leadership style. This statement is in agreement with the idea of Lord, De Vader and Alliger on the masculinity-femininity as a personality trait in forming leadership perceptions [30] and Carless believed that gender is the critical attribute that influences the variation of leaders' traits and attitudes [13]. However, the results contradict other previous studies that revealed females as being more transformational than male leaders [13]-[16], [31], [32]. This is because the current study reveals that male principals in Malaysian schools are more transformational than female counterparts.

According to Emrich, et al. [33] and Paris [34], the variation of leadership style is influenced by societal culture's perspective as "the same concepts may contain specific thought, processes, beliefs, implicit understandings, or behaviors in one culture, not another." The result is confirmed by Kawatra and Krishnan, who proclaimed that the creation of innovative culture is enhanced by transformational leadership and femininity [35]. However, it contradicts previous studies indicating that males are more likely to use power significantly than females [17] and employees become more innovative when transformational leadership is displayed by male leaders [16]. These contradicting results may be caused by sex-role stereotyping limiting women's perceived fit for certain administrative positions [36]. Meanwhile, Judge \& Piccolo [37] and Yammarino, et al. [38] revealed that although transformational leadership can be recognized as effective leadership behavior, it does not work for female leaders when they have male subordinates.

Furthermore, Ayman, Korabik, and Morris found that male subordinates, compared to female subordinates, are more negative in their evaluation when a female leader considers herself high on the transformational leadership behaviors [39]. Bartling believes that females can be as effective as males in their leadership [40]. However, the failure of recognizing them as good leaders is simply because of the sex-role stereotyping, which can be reduced by improving the level of gender egalitarianism in society. Thus, women have to outperform men to be considered equally competent [41].

This study has provided a glimpse of male and female school principals' transformational leadership behavior and its relation to teachers' innovative behavior. Based on this study's results, the priority is given by transformational leaders (regardless of their gender) to inspirational motivation inspires and motivates teachers to achieve results more significantly than the leaders have ever imagined. This is followed by intellectual stimulation that challenges the teachers' thinking about problem-solving strategies. It also promotes creativity and innovation. Next, individualized consideration, which refers to the leader's concern for individual teachers' unique gifts and talents, positively contributes to the teachers' IWB. Less priority is given to idealized influence, which is also known as charismatic leadership. It nevertheless has a good impact in this scenario as it leads to the creation of achievement-oriented cultures, which, for the most part, are advantageous. However, these results only relied on the items and constructs adapted from previous studies and rated based on teachers' perception. Thus, to have a comprehensive explanation, it is suggested to have a qualitative study that explores this issue from male and female principals' perspective. Their perspective will explain many shortfalls that would exist in quantitative research.

\section{CONCLUSION}

In sum, it can be concluded that the effectiveness of transformational leadership does not depend on the level of practice but on the efficiency of the leadership practice to reduce the negative perception of employees about the political environment in their workplace and improve their innovative work behavior. Gender is revealed as an essential individual trait that affects leadership style and has a significant impact on employees' innovative behavior. 


\section{ACKNOWLEDGEMENTS}

The Universiti Sains Malaysia supported this work under the Research University Grant [number 1001/PGURU/816254].

\section{REFERENCES}

[1] R. Bysted, "Innovative employee behaviour the moderating effects of mental involvement and job satisfaction on contextual variables," European Journal of Innovation Management, vol. 16, pp. 268-284, 2013.

[2] R. Bysted and J. Hansen, "Comparing public and private sector employees' innovative behaviour," Public Management Review, vol. 17, pp. 698-717, 2015.

[3] A. Klaeijsen, M. Vermeulen and R. Martens, "Teachers' Innovative Behaviour: The Importance of Basic Psychological Need Satisfaction, Intrinsic Motivation, and Occupational Self-Efficacy," Scandinavian Journal of Educational Research, vol. 62, no. 5, pp. 769-782, 2018.

[4] A. Sawasn, E. Ibrahim and J. Moizer, "Transformational leadership and innovation: the mediating role of knowledge sharing amongst higher education faculty," International Journal of Leadership in Education, 2019, doi: 10.1080/13603124.2019.1588381.

[5] B. Afsar, F. Yuosre Badir and B. Saeed, "Transformational leadership and innovative work behavior," Industrial Management and Data Systems, vol. 114, pp. 1270-1300, 2014.

[6] L. Gumusluoglu and I. Arzu, "Transformational Leadership, Creativity, and Organizational Innovation," Journal of Business Research, vol. 62, pp. 461-473, 2009.

[7] A. Zahari and K. Abd Latif, "The Effects of Transformational Leadership towards Teachers Innovative Behavior in Schools," International Journal of Scientific and Research Publications, vol. 6, pp. 283-286, 2016.

[8] B.M. Bass and B.J. Avolio, "Potential biases in leadership measures: How prototypes, lenience and general satisfaction relate to ratings and rankings of transformational and transactional leadership constructs," Educational and Psychological Measurement, vol. 49, pp. 509-527, 2009.

[9] M. Padgett, C.B. Cadwell and A. Embry, "Can Leaders Step Outside of the Gender Box? An Examination of Leadership and Gender Role Stereotypes," Scholarship and Professional Work - Business, vol. 71, pp. 1-23, 2008.

[10] C.H. Yuhanis and M.H. Mohd. Hisham, "The influence of gender and culture on transformational and transactional leadership styles," International Journal of Vocational Education and Training Research, vol. 1, no. 1, pp 10-15, 2015.

[11] S.M. Ting, "A Comparison of Gender on Leadership Styles and Its Relationship Towards Organizational Commitment," Bachelor Final Project Report, Universiti Malaysia Sarawak, Sarawak, 2015

[12] A.S.H. Bark, J. Escartin, S.C. Schuh and R. van Dick, "Who leads more and why? A mediation model from gender to leadership role occupancy," Journal of Business Ethics, vol. 139, no. 3, pp. 473-483, 2016.

[13] S.A. Carless, "Gender differences in transformational leadership: An examination of superior, leader, and subordinate perspectives," Sex Roles, vol. 39, pp. 887-902, 1998.

[14] H.R. Zeinabadi, "Social exchange outcomes of transformational leadership: Comparing male and female principals of public primary schools in Iran," International Journal of Educational Management, vol. 27, pp. 730-743, 2013

[15] M. Judeh, "Transformational Leadership: A Study of Gender Differences in Private Universities," International Review of Business Research Papers, vol. 6, pp. 118-125, 2010.

[16] M. Reuvers, M.L. van Engen, C.J. Vinkenburg, and E.Wilson-Evered, "Transformational leadership and innovative work behavior: exploring the relevance of gender differences," Creativity and Innovation Management, vol. 17, pp. 227-244, 2008.

[17] K. Rosenbusch and C. Townsend, "The Relationship of Gender and Organizational Setting to Transformational and Transactional Leadership Skills of Selected College Student Leaders," Journal of Leadership Education, vol. 3, pp. 4-20, 2004.

[18] N.A. Gilespie and L. Mann, "Transformational leadership and shared values: the building blocks of trust," Journal of Managerial Psychology, vol. 19, pp. 588-607, 2004.

[19] J. Rowold and K. Heinitz, "Transformational and charismatic leadership: Assessing the convergent, divergent and criterion validity of the MLQ and the CKS," The Leadership Quarterly, vol. 18, pp. 121-133, 2007.

[20] E. Vigoda, "Organizational Politics, Job Attitudes, and Work Outcomes: Exploration and Implications for the Public Sector," Journal of Vocational Behavior, vol. 57, pp. 326-347, 2000.

[21] H. van Emmerick, H. Wendt and M.C. Euwema, "Gender ratio, societal culture, and male and female leadership," Journal of Occupational and Organizational Psychology, vol. 00, pp. 1-21, 2009.

[22] Y. Cho, G.N. McLean, I. Amornpipat, C. Wei-Wen, G. I. Hewapathirana, M. Horimoto, et al., "Asian women in top management: eight country cases," Human Resource Development International, vol. 18, no. 4, pp. 407-428, 2015.

[23] Bernama, "Malaysia records higher women's participation in senior leadership: Grant Thornton," New Straits Time, March, 2018. [Online]. Available: https://www.nst.com.my/business/2018/03/342714/malaysia-records-higherwomens-participation-senior-leadership-grant.

[24] F. Mannan, S. Sharma, H. Kazi Enamul and J. Veeriah, "Predictive Validity of Gender and Experience of Teachers into Malaysian Women Principal's Instructional Leadership Practices," Malaysian Online Journal of Educational Management (MOJEM), vol. 4, no. 3, pp. 52-67, 2016. 
[25] Ministry of Education Malaysia, "Education for All 2015 National Review Report: Malaysia," 2015. [Online]. Available: https://unesdoc.unesco.org/ark:/48223/pf0000229719.

[26] A.F. Anas, "Empowering women, empowering Malaysia," Malaysia Kini, 2017. [Online]. Available: https://www.malaysiakini.com/letters/368977.

[27] S.M. Ting, "A Comparison of Gender on Leadership Styles and Its Relationship Towards Organizational Commitment," Bachelor Final Project Report, Universiti Malaysia Sarawak, Sarawak, 2015

[28] B.M. Bass and B. J. Avolio, Transformational leadership development: Manual for the Multifactor Leadership Questionnaire. Palo Alto, CA: Consulting Psychologist Press, 1990.

[29] O. Janssen, "Job demands, perceptions of effort-reward fairness, and innovative work behavior," Journal of Occupational and Organizational Psychology, vol. 73, pp. 287-302, 2000.

[30] R.G. Lord, C.L. De Vader, and G.M. Alliger, "A Meta-Analysis of the Relation between Personality Traits and Leadership Perceptions: Procedures," Journal of Applied Psychology, vol. 71, pp.402-410, 1999.

[31] T.W. Kent, C.A. Blair, H.F. Rudd, and U. Schuele, "Gender Differences and Transformational Leadership Behavior: Do Both German Men and Women Lead in the Same Way?" International Journal of Leadership Studies, vol. 6, pp. 52-66, 2010.

[32] K. Rosenbusch and C. Townsend, "The Relationship of Gender and Organizational Setting to Transformational and Transactional Leadership Skills of Selected College Student Leaders," The Journal of Leadership Education, vol. 3, pp. 4-20, 2004.

[33] C.G. Emrich, F.L. Denmark, and D.N. Den Hartog, "Cross-cultural differences in gender egalitarianism: Implications for societies, organizations, and leaders," In R. J. House, P. J. Hanges, M. Javidan, P. W. Dorfman and V. Gupta, Eds., Culture, leadership, and organizations: The GLOBE study of 62 societies. Thousand Oaks, CA: Sage Publication, 2004, pp. 343-394.

[34] L. Paris, The effect of gender and culture on implicit leadership theories: A cross-cultural study. Las Cruces, NM: New Mexico State University, 2003.

[35] S. Kawatra and V.R. Krishnan, "Impact of Gender and Transformational Leadership on Organizational Culture," NMIMS Management Review, vol. 16, pp. 1-6, 2004.

[36] E.A. Rusch, and C. Marshall, "Gender filters and leadership: Plotting a course to equity," International Journal of Leadership in Education, vol. 9, pp. 229-250, 2006.

[37] T.A. Judge and R.F Piccolo, "Transformational and transactional leadership: a meta-analytic test of their relative validity," Journal Applied Psychology, vol. 89, pp. 55-68, 2004.

[38] F.J. Yammarino, A.J. Dubinsky, L.B. Comer, and M. A. Jolson, "Women and transformational and contingent reward leadership: A multiple-levels-of-analysis perspective," Academy of Management Journal, vol. 40, pp. 205-222, 1997.

[39] R. Ayman, K. Korabik, and S. Morris, "Is Transformational Leadership Always Perceived as Effective? Male Subordinates' Devaluation of Female Transformational Leaders," Journal of Applied Social Psychology, vol. 39, pp. 852-879, 2009.

[40] E.M. Bartling, "Female High School Principals in Rural Midwestern School Districts: Their Lived Experiences in Leadership," Doctoral Dissertation, 2003. [Online]. Available: https://dc.uwm.edu/etd/75.

[41] L.A. Lord and A. Preston, "Understanding leadership experiences: the need for story sharing and feminist literature as a survival manual for leadership," Gender and Education, vol. 21, pp. 769-777, 2009. 